\title{
PEMENUHAN HAK-HAK DASAR ANAK DALAM PERSPEKTIF ISLAM
}

\author{
Burhanuddin \\ Dosen Fakultas Syariah dan Hukum \\ Universitas Islam Negeri Sunan Gunung Djati Bandung
}

\begin{abstract}
Abstrak
Dalam pandangan Islam, perlindungan anak memiliki makna fundamental, yaitu sebagai basis nilai dan paradigma untuk melakukan perubahan nasib anak, serta sebagai pendekatan komprehensif bagi manusia dalam pendidikan rohani, pembinaan generasi, pembentukan ummat, dan pembangunan budaya, serta penerapan prinsip-prinsip kemuliaan dan peradaban.
\end{abstract}

\section{Kata Kunci:}

Pemenuhan, Hak Dasar, Anak, Islam

\section{A. Pendahuluan}

Anak merupakan amanah sekaligus karunia dari Allah Tuhan Yang Maha Pencipta, bahkan anak dianggap sebagai harta kekayaan yang paling berharga dibandingkan kekayaan harta benda lainnya. Karenanya, anak sebagai amanah dari Allah swt harus senantiasa dijaga dan dilindungi karena dalam diri anak melekat harkat, martabat dan hak-hak sebagai manusia yang harus dijunjung tinggi. Hak dasar anak merupakan bagian hak asasi manusia seperti yang termaktub dalam Undang-Undang Dasar 1945 dan Konvensi Perserikatan Bangsa-bangsa tentang Hak-hak Anak. Dari konteks Negara, anak adalah pewaris dan sekaligus potret masa depan bangsa di masa datang, generasi penerus cita-cita bangsa, sehingga setiap anak berhak atas kelangsungan hidup, tumbuh dan berkembang secara normal, berpartisipasi serta berhak atas perlindungan dari tindak kekerasan dan diskriminasi.

Undang-undang Nomor 39 Tahun 1999 tentang Hak Asasi Manusia telah mencantumkan tentang Hak Anak, pelaksanaan kewajiban dan tanggung jawab orang tua, keluarga, masyarakat, pemerintah, dan negara untuk memberikan perlindungan terhadap 
286 | Adliya, Vol. 8 No. 1, Edisi: Januari-Juni 2014

anak. Undang-undang nomor 23 Tahun 2002 tentang Perlindungan Anak telah menegaskan bahwa pertanggungjawaban orang tua, keluarga, masyarakat, pemerintah dan negara merupakan rangkaian kegiatan yang dilaksanakan secara terus menerus demi terlindungnya hak-hak dasar anak.

Dalam pandangan Islam, perlindungan anak memiliki makna fundamental, yaitu sebagai basis nilai dan paradigma untuk melakukan perubahan nasib anak, serta sebagai pendekatan komprehensif bagi manusia dalam pendidikan rohani, pembinaan generasi, pembentukan ummat, dan pembangunan budaya, serta penerapan prinsip-prinsip kemuliaan dan peradaban.

Upaya perlindungan terhadap anak perlu dilaksanakan sedini mungkin, yakni sejak dari janin dalam kandungan sampai anak berusia 18 (delapan belas) tahun. Hal ini bertitik tolak dari konsepsi perlindungan anak yang utuh, menyeluruh, dan komprehensif.

\section{B. Pengertian dan Kedudukan Hukum Anak}

Anak adalah seorang yang belum berusia 18 tahun, termasuk anak yang masih dalam kandungan ${ }^{1}$. Hakekat kedudukan anak adalah tidak saja sebagai rahmat, tetapi juga sebagai amanah dari Allah SWT.

Dikatakan rahmat karena anak adalah pemberian Allah SWT yang tidak semua orangtua mendapatkannya. Allah menganugerahi anak hanya bagi keluarga yang dikehendakinya. Di sekeliling kita terkadang terlihat ada keluarga yang begitu ingin memiliki anak sampai mengahabiskan biaya banyak untuk mengupayakannya akan tetapi karena Allah belum berkehendak ia tetap belum dikaruniai anak. Sebagai amanah berarti ada kewajiban semua pihak untuk memberikan perlindungan pada anak, khususnya pemerintah pada level komunal dan orangtua pada level individual.

Sebagai bagian tak terpisahkan dari rahmat itu, Allah menanamkan perasaan kasih sayang orangtua pada anaknya. Setiap orangtua di dalam hatinya tertanam perasaan mengasihi dan menyayangi anaknya. Perasaan tersebut Allah tanamkan dalam hati para

${ }^{1}$ Pasal 1 (1)Undang-undang Nomor 23 Tahun 2002 tentang Perlindungan Anak. 
orangtua sebagai bekal dan dorongan dalam mendidik, memelihara, melindungi dan memperhatikan kemaslahatan anak-anak mereka sehingga semua hak anak dapat terpenuhi dengan baik serta terhindar dari setiap tindak kekerasan dan diskriminasi. Al-Qur'an menggambarkan perasaan itu dengan gambaran yang begitu indah:

Harta dan anak adalah perbiasan kehidupan dunia ....(QS. AlKahfi:46).

Dalam surat yang lain dikatakan:

...dan Kami menyiapkan dengan harta kekayaan dan anak-anak dan Kami jadikan kamu kelompok yang lebih besar (QS.A1-Isra':6)

Sesekali pula Al-Qur'an memandang anak sebagai pelipur hati, bila saja mereka sejalan dengan orang-orang yang bertakwa:

Dan orang-orang yang berkata, "Ya Tuban kami, anugerabkanlah kepada kami istri-istri kami dan keturunan kami sebagai penyenang hati (kami), dan jadikanlah kami imam bagi orang-orang yang bertaqwa (QS. Al-Furqan:74).

Sejak awal kehidupannya, termasuk ketika anak masih dalam kandungan. Manusia dilindungi oleh hukum sepanjang kepentingannya menghendaki. Dengan demikian, setiap manusia diakui sebagai subjek hukum yaitu pendukung hak dan kewajiban ${ }^{2}$.

Kedudukan hukum seorang anak sangat tergantung atas status sebuah hubungan perkawinan. Hubungan perkawinan ini di Indonesia diatur dalam Undang-undang Nomor 1 Tahun 1974 yang didalamnya mencakup keluarga, harta perkawinan, pemeliharaan anak, perceraian.

Perkawinan adalah pertalian yang antara seorang laki-laki dengan seorang perempuan dalam waktu yang lama. ${ }^{3}$ adapun di dalam Pasal 1 Undang-undang Nomor 1 Tahun 1974 menyebutkan : "Perkawinan adalah ikatan lahir batin antara seorang pria dengan seorang wanita sebagai suami istri dengan tujuan membentuk keluarga (rumah tangga) yang bahagia dan kekal berdasarkan Ketuhanan Yang Maha Esa".

Menurut Undang-undang Nomor 1 Tahun 1974, suatu perkawinan bertujuan untuk membentuk suatu keluarga yang bahagia

${ }^{2}$ Riduan Syahrani, Seluk-Beluk dan Asas-Asas Hukum Perdata. Alumni. Bandung, 1989. hlm 44.

3 Subekti. Pokok-pokok Hukum Perdata. Intermasa Jakarta.1984. hlm 23. 
288 | Adliya, Vol. 8 No. 1, Edisi: Januari-Juni 2014

dan kekal. Keluarga mempunyai peranan penting dalam kehidupan manusia sebagai mahluk sosial dan merupakan kesatuan masyarakat terkecil yang terdiri dari Ayah, Ibu dan anak. Dengan demikian pembentukan keluarga antara lain untuk memperoleh keturunan.

\section{Hakekat Perlindungan Anak}

Hakekat perlindungan anak dalam Islam adalah penampakan kasih sayang, yang diwujudkan kedalam pemenuhan hak dasar, dan pemberian perlindungan dari tindakan kekerasan dan perbuatan diskriminasi. Jika demikian halnya, perlindungan anak dalam Islam berarti menampakkan apa yang dianugerahkan oleh Allah SWT di dalam hati kedua orang tua yaitu berupa sentuhan cinta dan kasih sayang terhadap anak dengan memenuhi semua kebutuhan hak-hak dasarnya sehingga anak dapat hidup, tumbuh, berkembang dan berpartisipasi secara optimal serta melindungi anak dari setiap tindakan kekerasan dan ketidakadilan atas dasar menghormati dan memelihara harkat dan martabat anak sebagai anugerah dan amanah ciptaan Allah.

Dalam diri orangtua, Allah menanamkan perasaan cinta dan kasih sayang terhadap anaknya. Perasaan cinta dan kasih sayang yang diwujudkan dalam bentuk pemenuhan kebutuhan anak baik jasmani maupun rohani, serta melindungi anak dari setiap tindak kekerasan dan diskriminasi akan berpengaruh baik pada tumbuh kembang anak sehingga anak memiliki mental yang kuat dan tangguh, dan modal untuk meraih keberhasilan dan kesuksesan kelak di kemudian hari. Betapa pentingnya peran kasih sayang orangtua pada tumbuh kebang anak, Rasulullah mengingatkan dalam Haditsnya:

Tidaklah termasuk golongan kami, orang-orang yang tidak mengasibi anak kecil di antara kami dan tidak mengetahui hake orang besar di antara kami (HR Abu Daud dan Tirmidri)

Hadist tersebut diatas menunjukkan bahwa kasih sayang dalam perlindungan anak merupakan hakekat, yaitu sebagai fundamental dan motivasi bagi kewajiban pemenuhan hak dasar dan perlindungan anak. Pemenuhan itu diwujudkan dalam merawat, menjaga, membesarkan, mendidik, membina dan melindungi agar anak dapat tumbuh kembang secara optimal, baik secara fisik, mental, maupun sosial 
sehingga menjadi anak yang berkualitas, mempunyai akhlak yang mulia, dan sejahtera lahir dan bathin.

\section{Pemenuhan Hak Dasar Anak}

Mengacu pada tujuan disyariatkan Hukum Islam, yakni terciptanya suatu kemashlahatan umat manusia, maka ihwal perlindungan atas hak anak erat kaitannya dengan upaya memelihara keturunan (bifzh al-nasl) yang dalam rumusan Maqashid al-Syariah merupakan salah satu pilar ${ }^{4}$ yang mesti ditegakkan bagi terciptanya suatu kemashlahatan. Oleh sebab itu perlindungan atas hak-hak anak menjadi sangat penting, dan bagi kaum muslimin hukumnya menjadi wajib syar'i, yakni kewajiban sesuai dengan tuntutan syari'at (berpahala bagi yang melaksanakanya, berdosa bagi yang mengabaikannya).

Pemikiran di atas sangat relevan dengan beberapa petunjuk syara' sebagaimana dalam Al-Quran Surat al-Tabrim ayat 6 yang berbunyi:

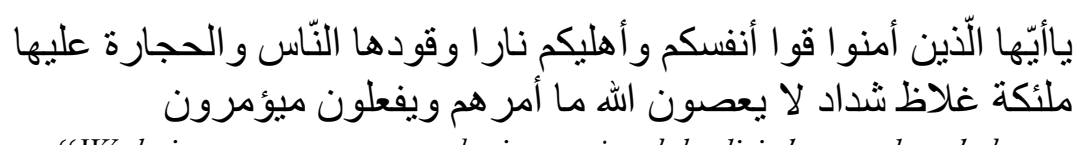

"Wahai orang-orang yang beriman, jagalah diri kamu dan keluarga kamu dari api neraka yang bahan bakarnya adaah manusia dan bebatuan. Penjaganya para malaikat yang kasar dan keras yang tidake pernah mendurhakai Allah terhadap apa yang diperintabkan-Nya kepada mereka dan selalu mengerjakan apa yang diperintabkan".

Ayat di atas mengisyaratkan secara tegas bahwa terbentuknya keluarga sakinah yang penuh kebaikan serta terhindar dari keburukan yang menyebabkan terjerumusnya ke dalam api neraka adalah tuntutan syara'. Dalam hal ini sudah barang tentu kepala keluarga memegang peranan sangat strategis dalam menentukan baik buruknya sebuah keluarga.

Pemenuhan hak dasar anak merupakan bagian integral dari implementasi pemenuhan hak asasi manusia. Dalam perspektif Islam, hak asasi anak merupakan pemberian Allah yang harus dija-

${ }^{4}$ Al-Syatibi dalam kitabnya al-Muwafaqat merumuskan Maqashid al-Syari'ah kepada lima hal, yakni terpeliharanya agama (bif $2 b$ al-din), terpeliharanya jiwa ( nash) dan terpeliharanya harta (bifz $h$ al-mal). 
290 | Adliya, Vol. 8 No. 1, Edisi: Januari-Juni 2014

min, dilindungi dan dipenuhi oleh orangtua, keluarga, masyarakat, pemerintah dan negara. Dalam Islam dikenal lima macam hak dasar yang disebut adh-dharuriyat al-khams, yaitu pemeliharaan atas kehormatan (hifdzul'ird) dan keturunan/nasab (hifdzun nasb), pemeliharaan atas hak beragama (bifdzud dien), pemeliharaan atas jiwa (bifdzun nafs), pemeliharaan atas akal (bifdzul aql), dan pemeliharaan atas harta (bifdzul mal).

\section{Hifdzud dien}

Pemeliharaan hak agama dalam Islam disebut bifdzud dien ${ }^{2}$ Pemeliharaan hak agama bagi anak dalam Islam pertama kali harus dilakukan oleh kedua orangtua terutama ibu, sebagai orangtua yang mengandung dan membesarkan anak. Agama anak mengikuti agama orangtuanya. Dari Abu Hurairah ra, dia berkata, Rasulullah SAW bersabda :

Setiap anak dilabirkan dalam keadaan fitrah (perasaan percaya kepada Allab). Maka kedua orangtuanyalah yang menjadikan anak tersebut beragama Yahudi, atau Nasrani ataupun Majusi (HR.Bukhari) ${ }^{5}$

Berdasarkan Hadist diatas orangtua mempunyai pengaruh yang sangat besar pada diri anak, baik dengan perkataan, keteladanan, cinta dan kasih sayang. Anak senantiasa banyak meniru orangtuanya.

Pembinaan keagamaan pada anak dapat dimulai ketika anak masih berada dalam kandungan dengan membiasakan anak mendengarkan bunyi-bunyian thoyibah seperti salawat, bacaan Al-Qur'an dan lain-lainnya. Anak yang dibiasakan mendengarkan kalimatkalimat thoyyibah sejak berada dalam kandungan, ia lebih mudah tanggap terhadap apa yang diajarkannya selama pertumbuhannya.

Setelah anak lahir ke dunia, orangtua wajib melakukan pembinaan keagamaan terhadap anaknya masing-masing, yaitu dalam bentuk penanaman keimanan, latihan beribadah, dan pembelajaran

${ }^{5}$ Dalam UU/23/2002 pasal 42 (1) menjelaskan bahwa anak mendapat perlindungan untuk benbadah menurut agamanya. Kemudian dalam ayat (2) dijelaskan bahwa agama yang dipeluk anak mengikuti orang tuanya sebelum ia dapat menentukan pilihannya. Yang bertanggung jawab terhadap hak tersebut dijelaskan dalam pasal 43 (1) adalah negara, pemerintah, masyarakat, keluarga, orangtua, wali dan lembaga sosial. Adapun tanggung jawabnya meliputi: 1) pembinaan. pembimbingan, dan pengamalan ajaran agama bagi anak. 
hukum agama. Dalam konteks ini, orangtua wajib mengajarkan dasar-dasar agama kepada anaknya, yaitu dengan memantapkan penanaman iman di dalam benaknya dengan mengumandangkan adzan dan ikamat di telinga anak ketika baru lahir. Akan hal ini Rasulullah telah memberikan contoh :

Aku melibat Rasulullab SAW mengumandangkan adzan pada telinga Al-Hasan bin Ali, ketika Fatimah melabirkannya (HR.Abu Dauddan Tirmidzi).

Rasulullah SAW bersabda :

Siapa yang baru mendapatkan bayi, kemudian ia mengumandangkan azan pada telinga kanannya dan ikamat pada telinga kirinya maka anak yang baru labir tidak akan terkena bahaya Ummush Syibyan ${ }^{6}$ (HR. Baibaqi dan Ibnu Sunni).

Ketentuan tersebut memberikan kejelasan bahwa hak agama anak selama anak belum dewasa berada dalam bimbingan orangtua. Rasulullah SAW bersabda:

Perintabkan anak-anakmu menjalankan ibadah shalat jika mereka sudah berusia tujub tabun. Dan jikea mereka sudab berusia sepulub tahun, maka pukullah mereka jika tidak mau melaksanakannya dan pisabkanlah tempat tidur mereka (HRAl-Hakim dan Abu Daud).

Dalil tersebut mengajarkan pada kita dua hal. Pertama, agar ketika anak beranjak dewasa memasuki usia baligh telah mengenal perintah dan larangan Allah, memahami hukum halal dan haram serta terikat dengan hukum syariat sehingga mampu melaksanakan perintahnya, dan menjauhi larangannya, serta tidak mudah tergelincir kejalan yang tidak diridhai-Nya. Pembiasaan itu biasanya dimulai dalam shalat dan puasa, tujuannya adalah untuk membiasakan dan mendorong anak untuk terbiasa sholat dan puasa sehingga ketika anak mencapai usia baligh anak sudah dalam keadaan siap secara jiwa dan raga untuk melakukan sholat dan puasa. Kedua, agar anak terbiasa melakukan dan terdidik untuk mentaati Allah, melaksanakan hak-Nya, bersyukur kepada-Nya, kembali kepada-Nya, berpegang teguh kepada-Nya, bersandar kepada-Nya, dan berserah diri kepada-

${ }^{6}$ Ummush Shibyan adalah angin yang dihembuskan pada anak, menjadikan anak takut kepadanya. Dikatakan, bahwa yang dimaksud adalah jin, yang oleh sebagian orang disebut qarinah 
292 | Adliya, Vol. 8 No. 1, Edisi: Januari-Juni 2014

Nya sehingga kesucian rohani, kebaikan akhlak dan perilaku sosialnya terjamin sejak dini sebagai bagian dari pemenuhan hak agama anak.

\section{Hifdzul 'ird dan Hifdzun nasb}

Salah satu bentuk dari hak sipil yang paling mendasar yang dimiliki oleh setiap anak yang terlahir ke muka bumi adalah hak untuk mendapatkan pengakuan akan jatidirinya yang terpatri dalam nama dan keturunan (nasab). Dalam legislasi nasional nama dan keturunan wajib tertuang dalam akte kelahiran sebagaimana telah ditegaskan dalam UU Nomor 23 Tahun 2006 tentang Administrasi Kependudukan dan Catatan Cipil. Dalam perpektif Islam hak sipil atau identitas seorang anak disebut dengan konsep hifdzul'ird (pemeliharaan atas kehormatan) dan hifdzun nasb (keturunan/ nasab).

Begitu pentingnya identitas bagi seorang anak dalam Islam sehingga sejak awal kelahirannya anak dianjurkan untuk segera diberi nama oleh orangtuanya. Pemberian nama tersebut dapat dilakukan tepat pada hari kelahirannya.

Rasulullah SAW bersabda.

"Setiap anak itu digadaikan dengan akikahnya. Di sembelibkan (binatang) baginya pada hari ketujuh (dari kelabiran)nya, diberi nama dan dicukur kepalanya pada hari itu pula."

Selain pemberian nama, yang termasuk hak sipil anak yang lain adalah hak untuk mencatatkan silsilah keturunan dari orangtuanya. Islam melarang adopsi yang menyebabkan anak kehilangan nasab orangtua kandungnya. Jika seorang anak diangkat oleh orang lain, pengangkatan tersebut tidak boleh sampai menyebabkan anak tersebut kehilangan nama ayah kandungnya. Di contohkan oleh Nabi SAW yang ketika itu mengangkat Zaid bin Haritsah. Pada awalnya orang menyebut Zaid sebagai Zaid bin Muhammad. Kemudian Allah SWT menegurnya: "Panggillah (anak-anak angkat itu) dengan (memakai) nama-nama bapak mereka, itulab yang lebih adil disisi Allah. " (QS. AlAhzab:5).

${ }^{7}$ Abdullah Nashih Ulwan, Tarbiyatul Aulad fil Islam. Penerbit Darussalam, Beirut. Diterjemahkan oleh Jamaluddin Miri, Pendidikan Anak dalam Islam, Jilid I dan II. Pustaka Amani, Jakarta 2002. Hlm. 73). 
Berdasarkan dalil tersebut dapat ditarik pemikiran bahwa hak sipil anak dalam pandangan Islam meliputi beberapa hal. Pertama, demi menjaga hak dan martabat anak, nama ayah kandung anak tidak boleh diganti dengan nama orang lain walaupun anak tersebut menjadi anak angkat. Untuk itu, Islam mengajarkan anak diberi nama dan menyebut nama orang tuanya pada hari ketujuh sambil bersedekah pada orang banyak. Dari sudut Negara Modern (pemerintah) dapat dimaknai seakte kelabagai akte kelahiran sebagai hak yang wajib diberikan pada anak. Kedua, hak dan kehormatan terkait pula dengan kejiwaan anak, sebab jika anak dikenal sebagai anak tak berbapak atau keturunan tidak jelas, maka ia akan mengalami masalah besar dalam pertumbuhan kepribadiannya kelak. Kedua hal tersebut terkait dengan mubarramat dan warisyaitu aturan tentang wanita-wanita yang haram dinikahi (dianggap incest/menikah seketurunan). ${ }^{8}$

\section{Hifdzun nafs}

Penyelenggaraan hak kesehatan di dalam Islam di sebut hifdæun nafs (pemeliharaan atas jiwa) ${ }^{9}$ Menjaga kesehatan anak adalah suatu kewajiban, baik secara fisik maupun mental, agar anak dapat tumbuh kembang secara normal, tidak ditimpa penyakit fisik maupun mental. Upaya penyelenggaraan perlindungan hak kesehatan anak dilakukan sejak dalam kandungan.

Memelihara kesehatan anak pertama kali diberikan oleh orangtua, terutama ibu sebagai orangtua yang mengandungnya. Pemenuhan kebutuhan gizi dan vitamin yang cukup dan seimbang

${ }^{8}$ yaitu aturan tentang wanita-wanita yang haram dinikahi (dianggap incest/menikah seketurunan).

${ }^{9}$ Menurut UU 23/2002, pasal 44, 46 dan 47 penyelenggaraan kesehatan anak meliputi: 1) Peningkatan kesehatan bagi anak yang telah sehat, pencegahan bagi ahak yang beresiko, pengobatan bagi anak yang sakit, serta rehabilitasi. 2) Perlindungan terhadap anak dari pengambilan organ atau jaringan tubuh yang dapat mengganggu kesehatannya. Adapun yang bertanggung jawab adalah orangtua dan keluarga, masayarakat dan pemerintah. Berikut masing-masing wewenangnya : 1) Orangtua dan keluarga bertanggungjawab menjaga dan merawat kesehatan anak. 2) Masyarakat bertanggungjawab dengan cara berperan aktif dalam penyelenggaraan perlindungan anak di bidang kesehatan. Dan 3) Pemerintah menyediakan fasilitas dan menyelenggarakan upaya kesehatan dengan dukungan masyarakat dan memberikan pelayanan gratis bagi masyarakat yang kurang mampu 
294 | Adliya, Vol. 8 No. 1, Edisi: Januari-Juni 2014

saat berada dalam kandungan merupakan salah satu hak kesehatan yang harus diberikan kepada anak ${ }^{10}$. Disamping pemenuhan gizi, menghindari kekerasan terhadap anak, ketika anak berada dalam kandungan juga merupakan kewajiban. Kekerasan yang dialami anak meski ia berada dalam kandungan sangat berbahaya bagi perkembangan anak. Rasulullah bersabda.

Anak yang celaka adalah anak yang telah mendapatkan kesempitan di masa dalam perut ibunya (HR. Imam Muslim).

Perhatian Islam pada kesehatan anak, tidak saja diberikan pada saat pra-lahir, tetapi juga diberikan pada saat pasca-lahir. Pada pascalahir, pemeliharaan hak kesehatan anak diarahkan pada upaya pertumbuhan sehat, pencegahan dan penyembuhan. Pada level pertumbuhan, diantara upaya-upaya yang dapat dilakukan oleh orangtua agar anak dapat tumbuh menjadi sehat diantaranya melalui: radha'ah (penyusuan), khitan, upaya pencegahan dan penyembuhan.

Pemenuhan hak dasar kesehatan dalam Islam tidak saja dalam bentuk radhaah dan khitan, tetapi juga melalui pendekatan perlindungan yang berkelanjutan, yaitu dalam bentuk pencegahan dan pengobatan dari penyakit. Dalam Islam mencegah anak dari penyakit adalah wajib. Diantara cara untuk mencegah penyakit adalah: makan, minum secara teratur dan tidak berlebihan. Orangtua hendaklah membiasakan anak untuk makan, minum dan tidur berdasarkan aturan-aturan yang sehat.

\section{Hifdzul 'aq1}

Penyelenggaraan hak pendidikan anak merupakan pilar penting bagi upaya peningkatan derajat kemanusiaan dan pemajuan peradaban manusia yang dalam Islam dikenal dengan istilah bifdrul aql (pemeliharaan atas akal) ${ }^{11}$. Pendidikan sebagai hak anak mengandung

${ }^{10}$ Ubes Nur Islam, Mendidik Anak Dalam Kandungan, Gema Insani. Jakarta 2004. Hlm. 29

${ }^{11}$ Menurut UU 23/2002 pasal 48, 51, 52 dan 54 Penyelanggaraan perlindungan anak di bidang pendidikan dilaksanakan sebagai berikut: 1) Semua anak wajib belajar 9 (sembilan) tahun. 2) Memberikan kesempatan yang sama dan aksesibilitas untuk memperoleh pendidikan biasa dan pendidikan luar biasa bagi anak yang menyandang cacat fisik dan/atau mental. 3) Memberikan kesempatan dan aksesibilitas untuk memperoleh pendidikan kliusus bagi anak yang memiliki keunggulan. Dan 4) Melindungi anak dari tindakan kekerasan yang dilakukan oleh guru, pengelola sekolah atau teman-temannya ketika berada dalam lingkungan 
pengertian bahwa kewajiban pertama ada di pundak keluarga, khususnya orangtua, dan seluruh komponen orang-orang yang beriman. Allah berfirman :

Bacalab dengan (menyebut) nama Tuhanmu Yang Menciptakan. Dia telah menciptakan manusia dari segumpal darah, Bacalah, dan Tuhanmulah Yang Paling Pemurah, yang mengajar manusia dengan perantaraan Kalam. Dia mengajarkan kepada manusia apa yang tidak diketahuinya (QS.Al-Alaq:l-5).

Niscaya Allah akean meninggikean orang-orang yang beriman diantaramu dan orang-orang yang diberi ilmu pengetabuan beberapa derajat ....(QS.Al-Mujadalah: 11).

Disamping ayat-ayat Al-Qur'an, ditemukan pula sejumlah Hadits yang menggambarkan pentingnya penyelenggaraan hak pendidikan bagi anak. Diantaranya Rasulullah SAW bersabda :

Dunia ini terkutuk dan terkutuklah yang ada didalamnya, kecuali orang-orang yang mengingat Allah dan yang taat kepada-Nya serta orang-orang yang alim atau terpelajar (HR. Tirmidzi).

Apabila anak adam telah meninggal dunia, maka putuslah segala amal perbuatannya, kecuali tiga hal: sedekah jariyah, ilmu yang bermanfaat, atau anak saleh yang mendoakan (HR.Muslim).

Ajarkanlab kebaikan kepada anak-anak kamu dan keluarga kamu dan didiklah mereka (HR. Abdur Razzaq dan Sa 'id bin Mansur).

Didiklah anak-anak kamu pada tiga hal: mencintai Nabimu, mencintai keluarganya dan membaca Al-Qur'an. (HR. Ath-Thabrani).

Dalilyang disebutkan di atas memberikan pelajaran bahwa pada dasarnya pendidikan merupakan hak anak yang harus diberikan sejak dalam kandungan sebagai bagian integral dari upaya orangtua menjaga anaknya terjaga dari api neraka. Dalam hal ini. kedudukan

sekolah. Sedangkan yang bertanggungjawab dalam penyelenggaraan pendidikan menurut UU 23/2002 pasal 48, 49 dan 53 adalah orangtua. masyarakat dan pemerintah. Berikut masing-inasing wewenangnya : 1) Orangtua bertanggungjawab dan wajib memberikan hak pendidikan bagi anak. 2) Pemerintah bertanggungjawab dan wajib menyclenggarakan pendidikan dasar minimal 9 (sembilan) tahun untuk semua anak memberikan biaya pendidikan dan/atau bantuan euma-euma atau pelayanan khusus bagi anak dari keluarga kurang mampu. anak terlantar. dan anak yang bertempat tinggal di daerah terpencil. serta mendorong masyarakat untuk berpcran aktif. Dan 3) Masyarakat bertanggungjawab dengan berpcran aktif dalam penyelenggaraan perlindungan anak di bidang pendidikan. 
296 | Adliya, Vol. 8 No. 1, Edisi: Januari-Juni 2014

orangtua adalah pemangku kewajiban yang pertama. Apabila orangtua atau keluarga tidak mampu melaksanakan kewajibannya, maka masyarakat dan pemerintahlah yang mengambil tanggung jawab dan kewajiban tersebut. Dalam pengertian bahwa pemerintah sebagai pemangku kewajiban wajib mendorong dan menfasilitasi terselenggaranya pendidikan anak, karena dengan pendidikanlah derajat manusia ditinggikan oleh Allah, baik di dunia maupun di akhirat.

Peningkatan derajat manusia melalui pendidikan bisa terwujud apabila konsepsi pendidikan anak tidak hanya diarahkan untuk kemampuan intelektual saja, tetapi juga harus mengembangkan kemampuan mental dan spiritual anak. Dengan ini Rasulullah menganjurkan dengan sangat agar anak diajak untuk berakhlak mulia dengan cara mengembangkan amalan spritualitas yaitu untuk senantiasa memuji Allah setiap saat. ${ }^{12}$ Pendidikan spiritual ini terkait dengan pengembangan mental anak, karena dengan pendidikan spritual yang baik maka pada gilirannya dapat menampilkan anak sebagai sosok yang memiliki mental yang baik pula. Ada hubungan simbiosis antara spiritualis dan perilaku mental, dalam arti perilaku sosial seseorang merupakan cerminan olah spiritualnya. Dengan kata lain sikap sosial akan kering dan cenderung pragmatis bila tidak dibimbing oleh spritualitasnya. Hal ini menunjukkan bahwa Rasulullah SAW memberikan perlindungan terhadap akidah tauhid dan keimanan seorang anak sedini mungkin melalui pendidikan agama. Dalam hubungan inilah Al-Ghazali menganjurkan pendidikan anak melalui pembiasaan spiritual dan akhlak yang baik dalam kehidupan sosial sejak dini.

Pendidikan dalam kehidupan sosial, Rasulullah menunjukkan pentingnya mendidik anak untuk mampu mengendalikan emosi amarah, kemandirian dan keberanian diri. ${ }^{13}$ Marah adalah gejala jiwa

12'Maka bertasbislah kamu kepada Allah diwakui kamii berada <ii petang hari dan waktu kamu berada di waktu subuh, dan bagi-Nyalah segala puji dilangit dan dibumi dan diwaktu kamu berada di petang hari dan diwaktu kamu berada diwaktu zuhur."(QS. Ar-Ruum: 17-18).

${ }^{13} \mathrm{Nabi}$ SAW berkala kepadaku:"Wahai anakku, jika engkau ingin mengisi pagi da soremu untuk tidak memiliki sifat menipu kepada seseorang dihatimu. maka lakukanlah," kemudian Nabi berkata kepadaku:"Wahai anakku, itu termasuk 
yang menyebabkan naiknya nafsu amarah. Ada dua bentuk amarah yaitu, amarah positif dan amarah negatif. Amarah positif adalah amarah untuk memelihara diri, kehormatan. negara dan agama.

Disamping pendidikan pengendalian emosi, yang penting juga adalah bagaimana mendidik anak untuk hidup realistik, memiliki etos dan kemandirian. Yang dimaksud hidup realistik adalah membiasakan anak untuk hidup sederhana dan tidak larut dalam kenikmatan.

Banyak hadist menunjukkan bahwa Rasulullah SAW telah memberikan contoh kongkrit agar umatnya membiasakan diri untuk hidup mandiri, dengan tidak membiasakan hidup bermewahmewahan. Sikap kemandirian harus diikuti sikap keberanian diri. Bersikap berani merupakan salah satu tabiat terpuji bagi anak-anak. Hal ini sebagaimana di contohkan oleh Rasulullah SAW:

Ajarkanlah anak-anak kalian berenang dan memanah. Dan surublah mereka melompat ke atas punggung kuda dengan sekali lompatan (HR.Baihaqi).

Hadist diatas menunjukkan bahwa Rasulullah SAW pendidikan keberanian anak-anak dengan meminta anak-anak mengikuti perlombaan, karena perlombaan dapat menjadikan akal anak menjadi bersemangat dan mengembangkan bakat serta keberanian anak untuk berpacu meraih kemenangan.

Dapat disimpulkan bahwa pendidikan anak dalam Islam pada dasarnya merupakan hak dasar yang harus dipenuhi sejak anak dalam kandungan. Oleh karena itu, orangtua adalah pemangku kewajiban yang pertama, setelah itu baru masyarakat dan pemerintah. Dalam pandangan Islam, pendikan anak berbasis hak dan bersifat komprehensif, yaitu tidak saja dalam bentuk pemenuhan kongnitif, tetapi juga pemenuhan hak pembinaan akhlak dan spiritual sehingga anak bisa tumbuh kembang secara utuh dan optimal.

\section{Hifdzul Mal}

Islam memberikan perhatian yang sangat besar terhadap hak sosial setiap orang khususnya bagi kelompok rentan, yaitu orang miskin, perempuan dan anak dengan cara memberlakukan hak-hak

dari sunnahku, siapa yang menghidupkan sunnahku berarti dia sungguh mencintaiku. dan siapa yang mencintaiku maka ia bersamaku di surga."(HR.Turmudzi). 
298 | Adliya, Vol. 8 No. 1, Edisi: Januari-Juni 2014

dasar jaminan sosial. Islam telah mempelopori dunia dalam penanggulangan problema kemiskinan di dalam masyarakat dengan cara menyediakan Baitul Mal melalui pengumpulan zakat.

Islam telah mensyariatkan untuk memelihara Baitul Mal (Kas Negara) bagi zakat yang diurus oleh negara dan membagikan zakat itu kepada orang-orang yang berhak menerimanya, seperti: orang fakir, miskin, musafir, orang yang berhutang dan untuk membebaskan budak-budak. Allah berfirman :

Sesunggubnya zakat-zakat itu hanyalah untuk orang-orang fakir, miskin, pengurus zakat, para muallaf yang dibujuk hatinya, untuke (memerdekakan) budak, orang yang berbutang, untuk berjuang dijalan Allah dan orang-orang yang sedang dalam perjalanan, sebagai suatu ketetapan yang diwajibkan oleh Allah, dan Allah Maha Mengetahui lagi Maha Bijaksana (QS.At-Taubah:60).

\section{Sadda Rasulullah SAW :}

Sesungghnya Allah telah meletakean bagi orang-orang Muslim kaya dalam harta-harta mereka sebesar apa yang dapat melapangkan orangorang miskin mereka. Orang-orang fakir itu tidak akan susab ketika merasa lapar dan telanjang, kecuali karena apa yang diperbuat oleh-oleh orang-orang kaya diantara mereka. Ketahuilah bahwa Allah pasti akan memperbitungkan mereka dengan perbitungan yang keras dan mengazab mereka dengan azabyangsangatpedih (HR. Thabrani).

Islam menganggap pemberian bantuan kepada orang lapar dan miskin pada saat sulit dan susah, sebagai salah satu kewajiban terpenting.

Islam memberlakukan undang-undang jaminan keluarga bagi setiap anak yang lahir dari seorang muslim, baik itu anak seorang pejabat pemerintah, pegawai, pekerja, maupun rakyat biasa. Menurut Abu Ubaid ${ }^{14}$ meriwayatkan:

"Dari Umar r.a. babwa ia menetapkan pemberian bantuan bagi setiap anak yang lahir yang jumlahnya kira-kira seratus dirham. Dan setiap anak itu tumbuh, maka bantuan itu bertambah. Undang-undang seperti ini juga telah dijalankan oleh orang-orang setelahnya, seperti Usman, Ali dan khaliafh lainnya."

14 Abdullah Nashih Ulwan, op cit hlm 413 
Jaminan keluarga baik pangan maupun sandang bagi setiap anak ada dipundak seorang ayah sebagaimana firman Allah:

Dan kewajiban ayah adalah memberi makan dan pakaian kepada para ibu dengan cara yang ma'ruf (QS.Al-baqarab:233).

Dalam sebuah Hadits disebutkan bahwa:

Satu dinar engkau nafkahkan di jalan Allah, satu dinar engkau nafkabkan untuk memerdekakan hamba, satu dinar engkau nafkabkan kepada seorang miskin dan satu dinar engkau nafkabkan untuke keluargamu. Pabala yang paling besar adalah yang engkau nafkeabkan untuk keluargamu (HR. Muslim).

Begitu pentingnya orangtua dalam menanggung beban sosial ekonomi anak, maka Allah memberikan pahala yang besar bagi seorang ayah karena memberi nafkah kepada keluarga, sebaliknya jika ia tidak mau memberi nafkah kepada anak-anak dan keluarga, padahal ia mampu, ia akan memperoleh dosa yang besar. Untuk itulah Islam mewajibkan kepada pemerintah untuk menyediakan lapangan kerja bagi setiap orang yang mempunyai kemampuan. Dari uraian diatas diketahui bahwa Islam telah mengajarkan etos kerja, kerja keras terhadap orangtua untuk menghidupi anaknnya. Jika orangtua tidak mampu melaksanakan kewajiban dan tanggungjawabnya pemeliharaan terhadap anak-anak yang hidupnya kurang mampu bergeser pada masyarakat, pemerintah dan terus kepada negara. Islam menyadari betul bahwa kemiskinan dapat menyebabkan penyimpangan pada kejiwaan anak. Dalam prakteknya realitas kemiskinan ini dapat menyebabkan anak terperosok kepada perilaku menyimpang seperti; menjadi pelacur, anak jalanan, terlantar dan lain-lainnya, yang menyebabkan masa depan anak-anak menjadi suram.

\section{E. Penutup}

Anak adalah pemberian Allah SW'T yang tidak semua orangtua mendapatkannya. Allah menganugerahi anak hanya bagi keluarga yang dikehendakinya 
300 | Adliya, Vol. 8 No. 1, Edisi: Januari-Juni 2014

Hak dasar anak merupakan bagian hak asasi manusia seperti yang termaktub dalam Undang-Undang Dasar 1945 dan Konvensi Perserikatan Bangsa-bangsa tentang Hak-hak Anak.

Dalam perspektif Islam, hak asasi anak merupakan pemberian Allah yang harus dijamin, dilindungi dan dipenuhi oleh orangtua, keluarga, masyarakat, pemerintah dan negara. Dalam Islam dikenal lima macam hak dasar yang disebut adh-dharuriyat al-khams, yaitu pemeliharaan atas kehormatan (bifdzul'ird) dan keturunan/nasab (bifdrun nasb), pemeliharaan atas hak beragama (bifdzud dien), pemeliharaan atas jiwa (bifdzun nafs), pemeliharaan atas akal (bifdzul aql), dan pemeliharaan atas harta (bifdrul mal).

\section{DAFTAR PUSTAKA}

Abdullah Nashih Ulwan, Tarbiyatul Aulad fil Islam. Penerbit Darussalam, Beirut. Diterjemahkan oleh Jamaluddin Miri, Pendidikan Anak dalam Islam, Jilid I dan II. Pustaka Amani, Jakarta 2002.

Achmad Sunarto, Himpunan Hadits Qudsi, Eska Media Jakarta 2002 Asafri Jaya Bakri, Konsep Maqashid Syari'ah menurut Al-Syatibi, PT Raja Grafindo Persada, Jakarta. 1996.

Herlina Apong, Dkk. Perlindungan Anak (berdasarkan Undang-undang Nomor 23 Tabun 2002 tentang Perlindungan Anak UNICEF. 2003 Riduan Syahrani, Seluk-Beluk dan Asas-Asas Hukum Perdata. Alumni. Bandung, 1989.

Subekti, Pokok-pokok Hukum Perdata. Intermasa Jakarta.1984

Ubes Nur Islam, Mendidik. Anak Dalam Kandungan (Optimalisasi Potensi Anak Sejak Dini), Gema Insani. Jakarta 2004.

Wahbah Zuhaili dkk, Buku Pintar Al-Qur'an Seven in One, Terjemahkan oleh Imam Ghazali Masykur. PenerbitAlmahira, Jakarta 2008

Undang-undang Republik Indonesia Nomor 23 Tahun 2002 Tentang Perlindungan Anak

Undang-undang Republik Indonesia Nomor 39 Tahun 1999 Tentang Hak Asasi Manusia

Undang-undang Republik Indonesia Nomor 1 Tahun 1974 Tentang Perkawinan 